ing experiences of critical library instructors within various institutional settings, such as community colleges, service-learning programs, and high schools. Topics presented in this section include the importance of collaboration between librarians and departmental faculty, and the overlap between service-learning and information literacy. Section four discusses the use of unconventional texts and media sources, like Wikipedia, rather than the traditional use of library catalogs and scholarly databases. The aim of this section is to "encourage critical engagement with all kinds of materials, including the web resources we traditionally decry." The final section examines the function of institutional power as it relates to the shrinking role of librarians. The issue of whether critical library instruction is even possible within the current culture of many colleges and universities is also addressed. Chapters in this section focus on the many challenges to implementing critical library instruction, such as assessment, ACRL Information Literacy Competency Standards for Higher Education, and the shifting role of libraries and librarians. The collection concludes with short summaries about each of the book's contributors, an author index, and a subject index. In general, the editors of this work bring forth some interesting ideas, questions, and provocative proposals regarding library instruction. Most might be of interest to library instructors at institutions where there are opportunities beyond

\begin{tabular}{|lr|}
\hline \multicolumn{2}{|l|}{ Index to advertisers } \\
ACRL 2011 & 180 \\
American Economic Assoc & 166 \\
Annual Reviews & 104 \\
Archival Products & 190 \\
Brepols & 110 \\
Brill & $150-151$ \\
CHOICE Reviews Online & 198 \\
Coutts Library Services & cover 2 \\
EBSCO & cover 4 \\
ISTE & 109 \\
Modern Language Assoc & 103 \\
Oxford Journals & cover 3 \\
Palgrave Macmillan Journals & 107 \\
Palgrave Macmillan Books & 127 \\
\hline
\end{tabular}

a one-shot instructional session or where there is support for instruction involving interdisciplinary studies and problem-based learning. Some practitioners may find many of the suggestions to be lacking in overlap with standards such as the ACRL Competency Standards and with best practices for quantitative assessment. Disregarding these limitations, the editors of the book ask a stimulating question: "Would ideas that didn't always lead directly to outcomes find a home in our profession?" If you are able to answer this question in the positive, then perhaps you are the intended audience for this book. Regardless, a background understanding of the writings of Elmborg, Freire, or Kapitzke might benefit readers who are new to the topic of critical library instruction or critical pedagogy.-Anders Selhorst, Guilford Technical Community College.

\section{The Handbook of Art and Design Librari-} anship. Eds. Amanda Gluibizzi and Paul Glassman. London, U.K.: Facet Publishing, 2010. 330p. paper, \$115 (ISBN: 9781856047029).

Although much has been published about art librarianship, art libraries, and the information-seeking behavior of art students, that material is spread across journals, books, and digital literature. The Handbook of Art and Design Librarianship aims to bring together in a comprehensive resource the key issues affecting art libraries and librarians, and the uniqueness of these spaces and of their patrons.

Although the editors claim the handbook is the first art librarianship publication that has an international purview because it brings together authors from an international community, the vast majority of chapters were written by librarians in the United States. Furthermore, except for Nancy Fawley's chapter "Cultural Differences and Information Literacy Competencies," which discusses the cultural differences of art students at an American design school in Qatar, the book addresses art library-related issues in the western world. Nonetheless, the publication fills a gap in the scholarship. 
The handbook is a collection of papers written by art librarians and professionals in the United States, Canada, the United Kingdom, and the Middle East and is organized into four sections. The first and briefest section focuses on the intricacies of running and managing an art library including issues of accreditation, outreach, and trends in art librarianship. The second section covers collection management and the use of library materials in the arts, dealing specifically with special collections, art and technology, and scholarly communication, as well as cataloging and deaccessioning materials. Teaching and information literacy are the focus of the third section. The last section addresses issues of designing, promoting, and safeguarding library spaces.

The collection's strength lies in those chapters that cover the uniqueness of art students and of the field. Patrick Tomlin's chapter is an excellent introduction to the transformations of scholarly communication and their impact on art librarianship. He compares scholarly communication in the arts and in the fields of science, technology, and medicine and highlights that the well-known serials crisis is not as relevant in the arts, where the cost of journals is rather low. Rather, he points to what he calls the monograph crisis in the arts due to publishers producing fewer art monographs because of perceived production costs and lack of market. Tomlin also argues that, in the arts, like the sciences, commercial publishers now control and produce the materials subsidized by universities. As a result, he urges art and design librarians to take a greater role in emerging models of scholarly communication. Other chapters of particular interest are Sandra Ludig Brooke's chapter on the use of special collections and art history instruction; Catherine Haras' discussion of visual literature as it pertains to art history and how to engage students in the research process based on student observation of artwork; Wilson and McCarthy's chapter on multiple literacies and innovative classroom exercises that address different learning styles; and Ruth Wallach's chapter on the need for art librarians to be multidisciplinarians in response to the growing interdisciplinary nature of scholarship and the resulting need to serve students and faculty in other disciplines.

The collection does have three weaknesses. First, the chapters that provide the least amount of insight are those that do not focus on art and design students or research in these fields, but are general in scope and speak to librarianship in general. Perhaps papers on general trends in librarianship would have been useful if they raised new questions, concerns, or ideas. Second, some of the cataloging concerns regarding the physical description of items in ACCR2 are addressed in the new RDA cataloging rules. Finally, the biggest disappointment is lack of design-related chapters. Studio art and art history are heavily addressed; as a result, the handbook is much more a guide for art librarianship and not design. A chapter on special issues in design librarianship would have been a welcome addition. Although one of the papers discusses art-related topics in other fields such as English and history, there is no discussion of how to meet the interdisciplinary needs of design students and faculty who often need resources in the social sciences and business.

I would argue that it is not truly a handbook, in the sense that it cannot be used as a manual or reference work because it is not comprehensive. The chapters cover a variety of relevant topics, some of which are excellent introductions to issues in art librarianship. It lacks, however, any substantial discussion of design. The Handbook of Art and Design Librarianship is a useful resource for library science students who are interested in this specialized field, as well as professionals working in art libraries, who serve art students, faculty, and community members. The chapters on information literacy may also be of interest to librarians in general, who seek new and innovative ways to work with students in the classroom.-Amauri Serrano, Appalachian State University. 